\title{
PENATAAN PERMUKIMAN KUMUH MASYARAKAT PESISIR DI DESA SANGSIT
}

\author{
Putu Indra Christiawan ${ }^{1}$, I Putu Ananda Citra², Made Arie Wahyuni ${ }^{3}$ \\ ${ }^{1,2}$ Fakultas Hukum dan Ilmu Sosial, ${ }^{3}$ Fakultas Ekonomi \\ Universitas Pendidikan Ganesha \\ e-mail: indra.christiawan@undiksha.ac.id
}

\begin{abstract}
Abstrak
Desa Sangsit merupakan bagian dari wilayah Kabupaten Buleleng yang memiliki sumberdaya kelautan yang potensial. Kenyataan ini didukung dengan peningkatan produktivitas hasil tangkapan ikan, terutama masyarakat pesisir yang bermata-pencaharian sebagai nelayan. Meskipun produktivitas hasil tangkapan ikan meningkat, tetapi kondisi ekonomi masyarakat nelayan terkategori miskin. Kemiskinan ini dimanifestasikan dalam wujud permukiman kumuh. Berdasarkan dari fenomena tersebut, kegiatan ini memiliki tujuan untuk: (1) mendesain visi misi penataan permukiman kumuh masyarakat pesisir, (2) meningkatkan pengetahuan dan pemahaman masyarakat pesisir, khususnya masyarakat nelayan di dalam menjaga kualitas permukiman dan (3) menata permukiman kumuh masyarakat pesisir yang sejalan dengan upaya peningkatan kemampuan dan keterampilan masyarakat nelayan dalam menata permukiman skala mikro. Pelaksanaan inti kegiatan P2M ini dalam format pembinaan, pelatihan dan pendampingan yang mengkhusus pada masing-masing rumah mitra. Narasumber dalam kegiatan ini adalah pakar lingkungan dan permukiman, yaitu Prof. Dr. I Gede Astra Wesnawa, M.Si. Materi pembinaan dan pelatihan yang telah dilaksanakan meliputi identifikasi karakteristik permukiman kumuh dan strategi penataan permukiman kumuh serta praktek penataan permukiman kumuh skala mikro yang meliputi penataan bangunan rumah, fasilitas rumah, sanitasi, kondisi lingkungan dan penataan keindahan. Evaluasi kegiatan P2M ini dilakukan terhadap proses dan produk kegiatan. Evaluasi proses berupa penilaian kinerja yang meliputi semangat, kerjasama dan keterbukaan mitra termasuk kemampuan mitra dalam menata permukiman, sementara evaluasi produk dilakukan terhadap hasil kinerja mitra berupa hasil penataan pada masing-masing komponen permukiman skala mikro. Penskoran dilakukan dengan skala Likert dengan bantuan rubrik penilaian, serta dianalisis dan diinterpretasi secara deskriptif. Hasil kegiatan P2M ini berjalan sesuai dengan rencana dan disambut positif dan antusias oleh mitra. Pasca mengikuti kegiatan P2M terdapat peningkatan pengetahuan dan pemahaman serta kemampuan mitra di dalam menata permukiman kumuh untuk menjadi permukiman yang memenuhi syarat-syarat rumah sehat.
\end{abstract}

Kata kunci: Permukiman Kumuh, Penataan Permukiman Skala Mikro

\begin{abstract}
Sangsit village is part of the district of Buleleng that have the potential of marine resources. This fact is supported by the increased productivity of fish catches, especially coastal communities as fishermen. Although the fish catches productivity is increased, but the economic conditions of the fishermen communities are categorized poor. Poverty is manifested in the form of slums. Based on this phenomenon, these activities aim to: (1) designing the vision and mission of structuring the slums of coastal communities, (2) improving the knowledge and understanding of coastal communities, especially the fishing community in maintaining the quality of the housing and (3) organize the slums of coastal communities which is in line with efforts to increase the abilities and skills of fishing communities in managing micro-scale settlements. The core of implementation activity is in the format of coaching, training and mentoring in each house partners. Professional persons who give the knowledge in this activity are environmental experts and settlements, namely Prof. Dr. I Gede Astra Wesnawa, M.Sc. Coaching and training materials that have been implemented include the identification of the characteristics of slums and slum settlements strategies and practices of microscale slum settlements which include the arrangement of house building, house facilities, sanitation, environmental conditions and the aesthetic. This activity evaluation was conducted on processes and products. Evaluation process in the form of performance assessment that includes the spirit, cooperation and openness of partners including the ability of partners in managing the settlement, while the product evaluation conducted on the results of the performance of partners in the form of the arrangement of the individual components of micro-scale settlements. Likert scale is used to scoring
\end{abstract}


with an assessment rubric, and analyzed and interpreted descriptively. Results of this activity is progressing as planned and welcomed positive and enthusiastic partner. Post follow the activities of this activity there is an increased knowledge and understanding and ability in managing partner in the slums to become a settlement that meets the requirements of a healthy home.

Keywords: Slum Settlement, Micro Scale Settlement Arrangement

\section{PENDAHULUAN}

Pulau Bali sebagai bagian dari negara maritim Indonesia adalah wilayah kepulauan yang memiliki sumberdaya bahari yang sangat kaya dan berlimpah (biodiversity). Sumberdaya bahari ini terdiri dari keberlimpahan hasil tangkapan, keindahan terumbu karang, pantai yang eksotis dan berbagai kebermanfaatan dari hutan mangrove. Secara teoritis masyarakat pesisir pada umunya dan masyarakat nelayan pada khususnya adalah masyarakat yang memiliki tingkat kesejahteraan yang tinggi. Hal ini dikarenakan segmen masyarakat ini merupakan masyarakat dengan kehidupan dan penghidupan yang bersentuhan secara langsung dengan berbagai keberlimpahan sumberdaya hayati tersebut.

$$
\text { Kenyataan dari kondisi }
$$

kesejahteraan masyarakat pesisir, khususnya pada masyarakat nelayan sangat berlawanan dengan kondisi yang diharapkan. Sebagian besar masyarakat nelayan yang yang berdomisili di dekat pantai dan mencurahkan aktivitas ekonomi hanya pada aktivitas melaut memiliki kondisi sosial ekonomi yang rendah, bahkan beberapa berada di dalam lingkaran kemiskinan. Kondisi sosial ekonomi yang rendah ini terutama dialami kelompok nelayan sebagai masyarakat pesisir di Desa Sangsit, Kecamatan Sawan (BPS Kec.Sawan, 2014). Kondisi sosial ekonomi masyarakat pesisir, khususnya kelompok nelayan dapat ditunjukkan dengan tingkat pendapatan dan tingkat kekumuhan rumah tempat tinggal mereka. Hasil penelitian Sintiawati (2014) menunjukkan bahwa sebagian besar pendapatan rata-rata masyarakat pesisir yang bermata pencaharian nelayan di Desa Sangsit adalah dalam kisaran $\mathrm{Rp}$ 500.000 ,- hingga $\mathrm{Rp} 1.000 .000$ per bulan. Pendapatan tersebut secara individual bervariasi antara satu individu dengan individu lain dalam suatu kelompok. Berdasarkan hasil penelitian yang sama, ditemukan bahwa pendapatan terendah adalah kurang dari Rp 500.000,- dan tertinggi adalah sebesar $\mathrm{Rp} 2.000 .000$,perbulan. Pendapatan kelompok nelayan yang termasuk berpendapatan rendah tersebut juga disebutkan tidak secara konsisten didapatkan nelayan di setiap bulan.

Sementara dari sisi permukiman terlihat bahwa sebagian besar kondisi rumah tinggal dari masyarakat pesisir berada dalam kategori tidak layak huni dan cenderung bersifat kumuh (Wesnawa, 1993). Kondisi ini terlihat dari luas halaman yang sempit, sanitasi yang rendah, fasilitas pendukung yang tidak lengkap dan tata letak yang tidak sesuai dengan peruntukan, khususnya tata letak perlengkapan melaut (Suparlan, 1995).

Kemampuan sumberdaya finansial yang rendah secara langsung akan mengurangi perhatian masyarakat nelayan di dalam memperbaiki dan memelihara kualitas rumah. Hal ini dikarenakan sumberdaya finansial yang berasal dari pendapatan yang rendah hanya cukup untuk memenuhi kebutuhan pokok anggota keluarga. Kondisi ini akan mengakibatkan dampak permasalahan permukiman yang dihadapi oleh masyarakat pesisir akan menjadi lebih luas dan kompleks. Dampak negatif dari keberadaan permukiman kumuh ini tidak hanya bersifat mikro yang dialami langsung oleh pemukim, tetapi dapat bersifat meso maupun makro yang dirasakan juga oleh masyarakat yang berada di sekitar permukiman kumuh tersebut. Permasalahan permukiman kumuh ini akan dapat menurunkan kualitas lingkungan pesisir dan pantai, serta lebih jauh dapat merusakan ekosistem laut yang akan berdampak pada pengurangan hasil tangkapan ikan masyarakat pesisir yang bermata 
pencaharian sebagai nelayan di Desa Sangsit.

Berdasarkan permasalahan permukiman kumuh tersebut, maka diperlukan suatu solusi yang visioner. Solusi visioner yang dimaksud adalah solusi yang tidak hanya bersifat meningkatkan kualitas permukiman masyarakat nelayan, tetapi juga dapat sebagai pondasi awal di dalam pengembangan wilayah pesisir di Desa Sangsit. Solusi visioner yang dibutuhkan adalah dengan penataan permukiman masyarakat nelayan di Desa Sangsit. Penataan permukiman yang menjadi fokus kegiatan adalah penataan permukiman skala mikro. Penataan permukiman masyarakat nelayan skala mikro adalah penataan lingkungan satuan rumah tempat tinggal dari masyarakat tersebut. Penataan permukiman skala mikro ini meliputi penataan bangunan rumah, fasilitas rumah, sanitasi, kondisi lingkungan, aspek estetis dan aspek arsitektural. Penataan permukiman tersebut dibutuhkan sebagai upaya optimalisasi penataan kawasan permukiman masyarakat pesisir, eksplorasi sumberdaya wilayah pesisir dan pengembangan ekonomi pesisir.

\section{METODE}

Metode yang digunakan untuk memecahkan permasalahan permukiman kumuh masyarakat nelayan di Desa Sangsit terdiri dari 3 metode, yaitu pembinaan, pelatihan dan pendampingan. Pertama, pembinaan melalui diskusi tentang dampak negatif permukiman kumuh terhadap kualitas kehidupan dan penghidupan masyarakat pesisir, khususnya masyarakat nelayan di Desa Sangsit. Kedua, pelatihan tentang strategi penataan permukiman kumuh skala mikro yang secara langsung meningkatkan kualitas lingkungan tempat tinggal dan sekaligus meningkatkan kesadaran mandiri dalam menjaga kebersihan serta keteraturan sarana prasarana rumah tempat tinggal. Ketiga, pendampingan dalam menata permukiman kumuh skala mikro secara bertahap dengan pendekatan community based development Kegiatan pembinaan, pelatihan dan pendampingan yang dilaksanakan sangat diharapkan mampu untuk meningkatkan pemahaman dan kemampuan masyarakat berkaitan dengan membangun lingkungan permukiman yang lebih berkualitas dan layak huni, serta masyarakat yang memiliki kesadaran mandiri terhadap kondisi lingkungan tempat tinggal mereka.

\section{HASIL DAN PEMBAHASAN \\ Kegiatan Persiapan Pelaksanaan Program P2M}

Pada tahap awal pelaksanaan program P2M telah dilaksanakan kegiatan persiapan meliputi pengurusan ijin pelaksanaan, survei lokasi dan koordinasi dengan mitra, Kegiatan persiapan ini dilaksanakan selama 3 bulan, yaitu dari bulan Maret sampai pada bulan Juni 2016. Hasil kegiatan survei lokasi dan koordinasi adalah: (1) menetapkan 3 keluarga nelayan sebagai mitra, yaitu Bapak Kusniadi, Bapak M.Salim dan Bapak Hambali serta (2) waktu pelaksanaan kegiatan P2M ditetapkan mengambil hari Jum'at dengan pertimbangan bahwa pada hari itu ketiga mitra pada khususnya dan masyarakat nelayan pada umumnya tidak melaut karena adanya kegiatan Jum'atan, mengingat seluruh mitra adalah masyarakat muslim.

\section{Kegiatan Pembinaan}

Kegiatan pembinaan dilaksanakan pada hari Jumat tanggal 10 Juni 2016 bertempat di Banjar Pabean Sangsit, tepatnya pada halaman rumah salah satu mitra, yaitu Bapak Hambali. Kegiatan ini dilaksanakan selama 3 jam dari pukul 15.00 sampai pada pukul 18.00 WITA bersama tim pelaksana, narasumber, kepala dusun serta seluruh mitra. Kegiatan pembinaan dalam program P2M yang disampaikan kepada mitra ini merupakan transfer Ipteks tentang dampak negatif permukiman kumuh yang diawali dengan penyampaian batasan permukiman kumuh, karakteristik, faktor penyebab dan dampak negatif dari keberadaan permukiman kumuh. Secara tidak langsung terlihat bahwa mitra sebenarnya telah merasakan bahwa lingkungan tempat tinggal yang dimukimi termasuk ke dalam kategori kumuh. Akan tetapi, mereka belum memiliki 
pengetahuan untuk dapat mengidentifikasi faktor-faktor penyebab, proses serta bentuk kekumuhan, baik yang terdapat di dalam rumah maupun di lingkungan sekitar rumah. Berdasarkan kondisi tersebut, maka tim pelaksana P2M bersama narasumber memberikan pembinaan tentang dampak negatif permukiman kumuh secara mendetail, sehingga dapat memperkuat pola pikir mitra terhadap kondisi dan kualitas lingkungan tempat tinggal yang baik, sekaligus merancang visi misi penataan permukiman kumuh bersama mitra. Produk yang dihasilkan dalam kegiatan pembinaan ini adalah berupa rancangan visi misi penataan permukiman kumuh dan penilaian pola pikir mitra. Adapun visi misi penataan permukiman kumuh yang disepakati bersama adalah menciptakan permukiman nelayan yang sehat dengan mengedepankan kebersihan, keselamatan dan keamanan. Berdasarkan evaluasi hasil kegiatan menunjukkan bahwa pola pikir mitra terhadap dampak negatif permukiman kumuh tergolong baik dengan rerata skor 3,95. Dengan demikian seluruh mitra mampu memahami berbagai dampak negatif yang diakibatkan oleh kondisi dan kualitas lingkungan tempat tinggal yang kumuh, dan mampu mengidentifikasi penyebab dan proses permukiman kumuh.

\section{Kegiatan Pelatihan}

Kegiatan pelatihan dilaksanakan pada hari Jum'at tanggal 15 Juli 2016 dengan lokasi yang sama dengan tempat kegiatan pembinaan, yaitu bertempat di depan halaman rumah Bapak Hambali. Kegiatan ini dilaksanakan selama 3 jam dari pukul 15.00 sampai pada pukul 18.00 WITA bersama seluruh tim pelaksana P2M, narasumber, kepala dusun serta seluruh mitra. Kegiatan pelatihan dalam program P2M merupakan kegiatan lanjutan dari kegiatan pembinaan. Kegiatan pelatihan ini memfokuskan pada strategi penataan permukiman kumuh dengan mempresentasikan langkahlangkah dan bentuk nyata dari penataan permukiman kumuh yang sesuai dengan misi yang telah dirancang pada kegiatan pembinaan, yaitu kebersihan, keselamatan dan keamanan. Kegiatan pelatihan berjalan dengan baik dan lancar. Terutama ketika membahas dan mendiskusikan arahan dan bentuk strategi penataan permukiman kumuh yang akan dilaksanakan dengan menunjukkan komponen-komponen rumah yang ada pada masing-masing rumah mitra. Produk yang dihasilkan dalam kegiatan pelatihan ini adalah berupa penilaian strategi yang disusun oleh mitra dalam menata permukiman kumuh dan persiapan pelaksanaan penataan permukiman kumuh. Berdasarkan evaluasi hasil kegiatan menunjukkan bahwa terdapat beberapa kesamaan strategi penataan yang disusun oleh mitra seperti yang terlihat pada Tabel

Tabel 1. Rancangan Strategi Penataan Permukiman Kumuh

\begin{tabular}{|c|c|c|c|c|}
\hline \multirow[t]{2}{*}{ No } & \multirow[t]{2}{*}{ Penataan } & \multicolumn{3}{|c|}{ Strategi } \\
\hline & & Mitra 1 & Mitra 2 & Mitra 3 \\
\hline 1 & $\begin{array}{l}\text { Bangunan } \\
\text { Rumah }\end{array}$ & Memperbaiki pagar & $\begin{array}{l}\text { Memperbaiki } \\
\text { pagar }\end{array}$ & $\begin{array}{l}\text { Membatasi rumah } \\
\text { dengan pagar kayu }\end{array}$ \\
\hline 2 & $\begin{array}{l}\text { Fasilitas } \\
\text { Rumah }\end{array}$ & $\begin{array}{l}\text { Menempatkan alat } \\
\text { nelayan di atas meja }\end{array}$ & $\begin{array}{l}\text { Memerlukan } \\
\text { wadah khusus } \\
\text { untuk alat } \\
\text { nelayan }\end{array}$ & $\begin{array}{l}\text { Memerlukan wadah } \\
\text { khusus untuk alat } \\
\text { nelayan }\end{array}$ \\
\hline 3 & Sanitasi & $\begin{array}{l}\text { Menempatkan tempat } \\
\text { sampah di halaman } \\
\text { rumah }\end{array}$ & $\begin{array}{l}\text { Menyediakan } \\
\text { tempat sampah }\end{array}$ & $\begin{array}{l}\text { Menyediakan tempat } \\
\text { sampah }\end{array}$ \\
\hline 4 & Lingkungan & $\begin{array}{l}\text { Melakukan } \\
\text { penghijauan }\end{array}$ & $\begin{array}{l}\text { Melakukan } \\
\text { penghijauan }\end{array}$ & Melakukan penghijauan \\
\hline
\end{tabular}




\begin{tabular}{cclll}
\hline 5 & Keindahan & $\begin{array}{l}\text { Merapikan instalasi } \\
\text { kabel }\end{array}$ & $\begin{array}{l}\text { Merapikan } \\
\text { instalasi kabel }\end{array}$ & $\begin{array}{l}\text { Merapikan instalasi } \\
\text { kabel }\end{array}$ \\
6 & Arsitektural & $\begin{array}{l}\text { Menyusun dari yang } \\
\text { paling sering } \\
\text { digunakan }\end{array}$ & $\begin{array}{l}\text { Menyusun dari } \\
\text { yang paling } \\
\text { berat }\end{array}$ & $\begin{array}{l}\text { Menyusun sesuai } \\
\text { dengan fungsinya }\end{array}$ \\
\hline
\end{tabular}

Adapun persiapan pelaksanaan penataan permukiman kumuh yang telah disepakati bersama adalah menandai komponen rumah yang akan ditata, mempersiapkan sarana prasarana dan menentukan urutan waktu lokasi penataan. Secara keseluruhan kegiatan pelatihan ini terlaksana tanpa mengalami kendala. Bahkan mitra telah mengaplikasikan nilai kebersihan, keselamatan dan keamanan, yaitu dengan membiasakan diri untuk menyapu halaman rumah, menempatkan peralatan nelayan di satu tempat dan meletakkan peralatan nelayan yang berat dan berbahaya jauh dari jangkauan anak-anak mereka. Dengan demikian kegiatan pelatihan ini diharapkan dapat mempertinggi kepedulian mitra terhadap kondisi dan kualitas lingkungan tempat tinggal secara berkelanjutan, sehingga mitra dapat mewujudkan rumah sehat yang bersih, selamat dan aman.

\section{Kegiatan Pendampingan}

Kegiatan pendampingan dalam penataan permukiman kumuh masyarakat pesisir dilaksanakan selama 3 kali selama 3 minggu pada bulan Agustus, yaitu pada tanggal 5, 12 dan 19 Agustus 2016. Meskipun kegiatan pendampingan hanya menata 1 rumah pada setiap kali kegiatan, tetapi tetap mengikutsertakan seluruh mitra untuk mengetahui bersama tahapan kerja serta membandingkan komponen dan kondisi rumah mitra satu dengan yang lain. Dengan demikian seluruh mitra mendapatkan pengalaman yang semakin luas di dalam menata permukiman. 1) Kegiatan Pendampingan Pertama yaitu Kegiatan pendampingan pertama dilaksanakan pada hari Jum'at tanggal 5 Agustus 2016 di rumah Bapak Kusniadi. Secara garis besar inti kegiatan adalah menata komponen permukiman yang meliputi aspek bangunan, fasilitas, sanitasi, lingkungan hingga aspek keindahan rumah sesuai rancangan strategi penataan yang telah disusun; 2) Kegiatan pendampingan berjalan dengan baik dan lancar. Kondisi ini dikarenakan mitra sebagai pemilik rumah langsung sangat antusias dalam menata rumah secara mandiri. Di sisi lain, mitra yang lain juga mengamati. Dalam kegiatan pendampingan ini, terlihat bahwa mitra sudah memiliki kemampuan dan keterampilan dasar dalam menata permukiman secara mandiri. Akan tetapi, terdapat beberapa kesulitan yang dihadapi mitra pertama, khususnya pada aspek lingkungan di dalam menentukan posisi pemasangan pot tanaman gantung, dan aspek keindahan rumah di dalam menata instalasi kabel. Melihat kondisi tersebut, tim pelaksana segera membantu mitra di dalam menata aspek lingkungan dan keindahan rumah. Berdasarkan evaluasi kegiatan ditinjau dari proses, kemampuan dan hasil kerja menunjukkan bahwa penataan yang telah dilaksanakan mitra berkategori nilai yang tinggi dengan rerata skor 3,67 seperti terlihat pada Tabel 2 .

Tabel 2. Hasil Evaluasi Kegiatan Pendampingan Pertama

\begin{tabular}{cllll}
\hline No & Penilaian & Nilai & Rerata & Kategori \\
\hline 1 & Proses Kerja & 19 & 3,80 & Tinggi \\
2 & Kemampuan Kerja & 19 & 3,80 & Tinggi \\
3 & Hasil Kerja & 17 & 3,40 & Cukup \\
& Rerata & 18 & 3,67 & Tinggi \\
\hline \multicolumn{2}{r}{} & & \multicolumn{2}{c}{ Sumber: Data Primer, 2016 }
\end{tabular}


Dengan demikian seluruh mitra mampu memahami menata permukiman kumuh sesuai dengan strategi yang telah disusun. Kegiatan pendampingan pertama ini berjalan sesuai dengan rencana dan alokasi waktu kegiatan yang disusun; 3) Kegiatan Pendampingan Kedua yaitu Kegiatan pendampingan pertama dilaksanakan pada hari Jum'at tanggal 12 Agustus 2016 di rumah Bapak M.Salim. Kegiatan ini dilaksanakan selama 3 jam dari pukul 15.00 sampai pada pukul 18.00 WITA bersama seluruh tim pelaksana P2M, surveyor dan seluruh mitra. Secara garis besar kegiatan diawali dengan persiapan awal terkait alat dan bahan untuk penataan permukiman, dan kemudian dilanjutkan dengan menata komponen-komponen permukiman yang meliputi aspek bangunan, fasilitas, sanitasi, lingkungan hingga aspek keindahan rumah sesuai dengan rancangan strategi penataan yang telah disusun secara kolektif. Kegiatan pendampingan berjalan dengan baik dan lancar. Kondisi ini dikarenakan mitra sebagai pemilik rumah langsung sangat antusias dalam menata rumah secara mandiri, dan juga memiliki pengalaman sebelumnya pada kegiatan pendampingan pertama. Di sisi lain, mitra yang lain juga mengamati dan membandingkan komponen rumah mereka dengan rumah Bapak M.Salim. Dalam kegiatan pendampingan ini, terlihat bahwa mitra sudah memiliki kemampuan dan keterampilan dasar dalam menata permukiman secara mandiri. Mitra hanya mengahadapi kesulitan di dalam menentukan posisi pemasangan pot tanaman gantung, dan aspek keindahan rumah di dalam menata instalasi kabel. Melihat kondisi tersebut, tim pelaksana segera membantu mitra di dalam menata aspek lingkungan dan keindahan rumah. Berdasarkan evaluasi kegiatan ditinjau dari proses, kemampuan dan hasil kerja menunjukkan bahwa penataan yang telah dilaksanakan mitra tergolong nilai yang tinggi dengan rerata skor 4,07 seperti terlihat pada Tabel 3. Dengan demikian seluruh mitra mampu memahami menata permukiman kumuh sesuai dengan strategi yang telah disusun. Kegiatan pendampingan kedua ini berjalan lebih lancar dan sesuai dengan alokasi waktu kegiatan yang disusun.

Tabel 3. Hasil Evaluasi Kegiatan Pendampingan Kedua

\begin{tabular}{lllll}
\hline No & Penilaian & Minimum & Maksimum & Mean \\
\hline 1 & Proses Kerja & 20 & 4,00 & Tinggi \\
2 & Kemampuan Kerja & 21 & 4,20 & Tinggi \\
3 & Hasil Kerja & 20 & 4,00 & Tinggi \\
& Rerata & 20 & 4,07 & Tinggi \\
\hline & & & \multicolumn{2}{c}{ Sumber: Data Primer, 2016 }
\end{tabular}

\begin{abstract}
Kegiatan Pendampingan Ketiga Kegiatan pendampingan pertama dilaksanakan pada hari Jum'at tanggal 19 Agustus 2016 di rumah Bapak Hambali. Kegiatan ini dilaksanakan selama 3 jam dari pukul 15.00 sampai pada pukul 18.00 WITA. Secara garis besar kegiatan berjalan hampir sama dengan kegiatan pendampingan pertama dan kedua. Perbedaan yang nampak adalah bahwa mitra memiliki inisiatif untuk menata beberapa aspek permukiman lebih awal, sehingga pada saat kegiatan pendampingan hal utama yang dilakukan adalah menyempurnakan penataan yang
\end{abstract}

telah dilaksanakan oleh mitra ketiga. Kegiatan pendampingan berjalan dengan sangat baik dan lancar. Kondisi ini dikarenakan mitra sebagai pemilik rumah sudah memiliki pengalaman dan waktu lebih banyak dari kegiatan pendampingan pertama dan kedua. Di sisi lain, kedua mitra yang lain juga menyempurnakan kembali hasil penataan yang telah dilakukan pada pendampingan pertama dan kedua. Dalam kegiatan pendampingan terakhir ini, terlihat bahwa mitra sudah memiliki kemampuan dan keterampilan yang lengkap dalam menata permukiman secara mandiri dan penuh 
kreativitas, khususnya dalam menata aspek bangunan rumah, fasilitas rumah dan aspek keindahan rumah. Mitra tidak mengalami kesulitan apapun di dalam menata rumah. Melihat kondisi tersebut, tim pelaksana sangat mengapresiasi usaha dan inisiatif mandiri dari para mitra program. Berdasarkan evaluasi kegiatan ditinjau dari proses, kemampuan dan hasil kerja menunjukkan bahwa penataan yang telah dilaksanakan mitra tergolong sangat tinggi dengan rerata skor 4,73 seperti terlihat pada Tabel 4.

Tabel 4. Hasil Evaluasi Kegiatan Pendampingan Ketiga

\begin{tabular}{lllll}
\hline No & Penilaian & Nilai & Rerata & Kategori \\
\hline 1 & Proses Kerja & 23 & 4,60 & Sangat Tinggi \\
2 & Kemampuan Kerja & 24 & 4,80 & Sangat Tinggi \\
3 & Hasil Kerja & 24 & 4,80 & Sangat Tinggi \\
& Rerata & 24 & 4,73 & Sangat Tinggi \\
\hline & & & \multicolumn{2}{c}{ Sumber: Data Primer, 2016 }
\end{tabular}

Dengan demikian seluruh mitra mampu memahami menata permukiman kumuh sesuai dengan strategi yang telah disusun, dan bahkan melebihi ekspektasi awal. Kegiatan pendampingan ketiga ini berjalan sangat lancar dan dengan alokasi waktu kegiatan yang sangat efisien dan efektif.

\section{Kegiatan Evaluasi}

Kegiatan evaluasi telah dilaksanakan setiap akhir kegiatan, baik pembinaan, pelatihan maupun kegiatan pendampingan untuk menilai kemampuan mitra dalam menata permukiman kumuh skala mikro. Di samping itu, dilaksanakan juga evaluasi dampak dan refleksi dari program $\mathrm{P} 2 \mathrm{M}$ bersama seluruh mitra untuk mengetahui kebermanfaatan pembinaan, pelatihan dan pendampingan dalam penataan permukiman kumuh yang telah dilaksanakan oleh seluruh mitra. Dampak utama yang dirasakan dari mitra program adalah perubahan sosial yang meliputi: (1) rasa aman, mitra merasa aman berada di lingkungan tempat tinggal, (2) hubungan dengan keluarga yang semakin intens, (3) rasa tenang, mitra merasa tenang berada di dalam rumah,

\section{PENUTUP \\ Simpulan}

Berdasarkan pada rencana kegiatan yang telah dicapai dalam pelaksanaan program P2M ini, maka dapat disimpulkan sebagai berikut. Pertama, pelaksanaan kegiatan
(4) hubungan dengan tetangga yang juga semakin erat dan (5) rasa nyaman, yang membuat mitra merasa betah berada di rumah. Refleksi kegiatan yang dinilai adalah manfaat kegiatan, kesan selama kegiatan dan harapan mitra. Manfaat kegiatan yang dirasakan oleh seluruh mitra secara langsung adalah kondisi lingkungan tempat tinggal yang rapi, bersih, aman dan nyaman. Kesan selama kegiatan berlangsung adalah jalinan komunikasi dan saling memahami yang baik, serta kesederhanaan di dalam menyampaikan materi, sehingga dapat dipahami dengan baik oleh para mitra. Sedangkan harapan dari para mitra sebagian besar adalah agar kegiatan serupa yang bersentuhan langsung dalam meningkatkan kemampuan dan keterampilan masyarakat untuk menata rumah secara mandiri lebih dikhususkan pada aspek perbaikan dan pemeliharaan. Di sisi lain, mitra juga mengharapkan agar kegiatan selanjutnya secara langsung melibatkan seluruh anggota keluarga, termasuk anak-anak. Hal ini dipandang penting untuk memberikan pendidikan usia dini mengenai kesehatan lingkungan dan kesehatan rumah tempat tinggal. pembinaan terlaksana dengan baik, karena adanya motivasi dan partisipasi yang aktif dari seluruh mitra. Setelah kegiatan pembinaan, mitra menjadi memiliki pemahaman yang holistik mengenai faktor penyebab, proses dan bentuk dari dampak negatif dari permukiman kumuh. Kedua, pelaksanaan 
kegiatan pelatihan dapat mencapai hasil yang sesuai dengan rencana. Hal ini terlihat dari proses dan evaluasi yang dilaksanakan, yang menunjukkan antusiasme dan respon cepat dari mitra di dalam merancang strategi penataan permukiman kumuh skala mikro yang tepat sasaran. Kegiatan pelatihan ini telah mampu mempertinggi kepedulian mitra dalam mewujudkan rumah sehat berbasis kebersihan, keselamatan dan keamanan. Ketiga, pelaksanaan kegiatan pendampingan dapat mencapai hasil yang optimal, dan bahkan melebihi dari rencana awal. Hal ini terlihat dari proses kerja, kemampuan kerja dan hasil kerja yang berdasarkan hasil evaluasi menunjukkan kategori nilai yang tinggi, dan salah satu mencapai kategori nilai sangat tinggi. Kegiatan pendampingan ini telah mampu mempertinggi kemampuan dan keterampilan mitra secara mandiri dalam menata berbagai komponen permukiman.

\section{Saran}

Berdasarkan pada ketiga kegiatan pembinaan, pelatihan dan pendampingan yang telah dilaksanakan di Desa Sangsit. Dibutuhkan penataan yang bersifat kontinu dan meluas dari berbagai pihak, termasuk pemerintah, khususnya di wilayah pesisir Desa Sangsit, dan juga desa-desa pesisir lainnya di Kecamatan Sawan yang mayoritas penduduknya nelayan. Masyarakat pesisir, khususnya nelayan sangat membutuhkan informasi yang berkaitan dengan konsep dan pemahaman tentang lingkungan tempat tinggal yang layak huni serta kemampuan dan keterampilan dalam menata permukiman secara mandiri dan berkesesuaian dengan kondisi sosial ekonomi mereka.

\section{DAFTAR RUJUKAN}

Badan Pusat Statistik. 2014. Kecamatan Sawan Dalam Angka Tahun 2014.

Sintiawati, I Gusti Ayu Putu Meika. 2014. Karakteristik Dan Proses Terbentuknya Permukiman Kumuh Di Wilayah Pesisir Desa Sangsit (Kasus Desa Sangsit). Skripsi (tidak diterbitkan). Jurusan Pendidikan Geografi, Fakultas IImu Sosial, Universitas Pendidikan Ganesha Singaraja.

Suparlan, Supardi. 1995. Kemiskinan di Perkotaan. Jakarta: YOI.

Wesnawa, I Gede Astra. (1993). Program Perbaikan Kampung Dalam Rangka Penataan Permukiman Kumuh. Aneka Widya. Vol 4. (hal.181-187). 